\title{
The Intangible-Rights Doctrine and Political-Corruption Prosecutions Under the Federal Mail Fraud Statute
}

In recent years, federal prosecutors and courts have used the federal mail fraud statute, section 1341 of Title $18,{ }^{1}$ to combat political corruption at state and local levels. ${ }^{2}$ The greatly publicized convictions of the former governors of Illinois ${ }^{3}$ and Maryland ${ }^{4}$ were obtained under that section. The language of the statute, ${ }^{5}$ however,

118 U.S.C. \& 1341 (1976). See note 5 infra.

2 In many of these cases, convictions were based on conventional concepts of fraud. See Parr v. United States, 363 U.S. 370 (1960) (convictions reversed); United States v. Rauhoff, 525 F.2d 1170 (7th Cir. 1975); United States v. Bush, 522 F.2d 641 (7th Cir. 1975), cert. denied, 424 U.S. 977 (1976); United States v. Barrett, 505 F.2d 1091 (7th Cir. 1974), cert. denied, 421 U.S. 964 (1975); United States v. Staszcuk, 502 F.2d 875 (1974), rev'd in part on rehearing en banc, 517 F.2d 53 (7th Cir.), cert. denied, 423 U.S. 837 (1975); Bradford v. United States, 129 F.2d 274 (5th Cir.), cert. denied, 317 U.S. 683 (1942); Leche v. United States, 118 F.2d 246 (5th Cir.), cert. denied, 314 U.S. 617 (1941); Shushan v. United States, 117 F.2d 110 (5th Cir. 1941), cert. denied, 313 U.S. 574 (1942). In other cases, convictions were based on an expansive interpretation of fraud in the context of political corruption where citizens were said to have been deprived of certain intangible rights. See United States v. Mandel, 591 F.2d 1347 (4th Cir.), conviction aff'd in relevant part on rehearing en banc, 602 F.2d 653 (4th Cir. 1979) (per curiam), cert. denied, 100 S. Ct. 1647 (1980); United States v. Rabbit, 583 F.2d 1014 (8th Cir. 1978) (convictions arguably based on expansive interpretation of fraud), cert. denied, 439 U.S. 1116 (1979); United States v. McNeive, 536 F.2d 1245 (8th Cir. 1976) (expansive interpretation of fraud adopted in dictum; convictions reversed); United States v. Brown, 540 F.2d 364 (8th Cir. 1976); United States v. Keane, 522 F.2d 534 (7th Cir. 1975), cert denied, 474 U.S. 976 (1976); United States v. Isaacs, 493 F.2d 1124 (7th Cir.), cert. denied, 417 U.S. 976 (1974); United States v. States, 488 F.2d 761 (8th Cir. 1973), cert. denied, 417 U.S. 909 (1974); United States v. Fraser, 303 F. Supp. 380 (E.D. La. 1969) (expansive interpretation of fraud adopted in dictum); United States v. Randle, 39 F. Supp. 759 (W.D. La. 1941) (no convictions). It is this latter group of cases-adopting the intangible-rights theory in their expansive definition of fraud-that this comment analyzes.

${ }^{3}$ United States v. Isaacs, 493 F.2d 1124 (7th Cir.), cert. denied, 417 U.S. 976 (1974). Otto Kerner, the former governor, was a judge on the United States Court of Appeals for the Seventh Circuit at the time of his conviction.

- United States v. Mandel, 591 F.2d 1347 (4th Cir.), conviction aff'd in relevant part on rehearing en banc, 602 F.2d 653 (4th Cir. 1979) (per curiam), cert. denied, 100 S. Ct. 1647 (1980).

- Whoever, having devised or intending to devise any scheme or artifice to defraud, or for obtaining money or property by means of false or fraudulent pretenses, representa- 
does not specify political corruption as a target of its proscription. Rather, it uses general terms to prohibit "any scheme or artifice to defraud, or for obtaining money or property by means of false or fraudulent pretenses, representations, or promises." These words, the subject of extensive judicial construction, ${ }^{6}$ have provided the statutory basis for punishing certain forms of fraudulent public conduct.

Outside of the arena of political corruption, the mail fraud statute has been applied in schemes in which the victim of the fraud has transferred something of economic value to the defendant. ${ }^{7}$ Beginning with United States $v$. States ${ }^{8}$ in 1973, three circuits - the Fourth, ${ }^{9}$ Seventh, ${ }^{10}$ and Eighth ${ }^{11}$-have applied section 1341 to situations in which corrupt politicians did not deprive the citizens of anything of economic value. Their crime was said to consist of defrauding citizens of their rights to honest government. That an official may now be convicted under section 1341 when his purported scheme to defraud has as its sole object the intangible and abstract political and civil rights of the general citizenry is perhaps the most important development in the history of the mail fraud statute. ${ }^{12}$ In reaching their decisions, these courts have relied

tions, or promises, or to sell, dispose of, loan, exchange, alter, give away, distribute, supply, or furnish or procure for unlawful use any counterfeit or spurious coin, obligation, security, or other article, or anything represented to be or intimated or held out to be such counterfeit or spurious article, for the purpose of executing such scheme or artifice or attempting to do so, places in any post office or authorized depository for mail matter, or any matter or thing whatever to be sent or delivered by the Post Office Department, or takes or receives therefrom, any such matter or thing, or knowingly causes to be delivered by mail according to the direction thereon, or at the place at which it is directed to be delivered by the person to whom it is addressed, any such matter or thing, shall be fined not more than $\$ 1,000$ or imprisoned not more than five years, or both.

18 U.S.C. $\S 1341$ (1976).

- See United States v. McNeive, 536 F.2d 1245, 1247-48 (8th Cir. 1976).

- See text and notes at notes 12,61, 102, 144, 148, 150 infra.

- 488 F.2d 761 (8th Cir. 1973), cert. denied, 417 U.S. 909 (1974).

- United States v. Mandel, 591 F.2d 1347 (4th Cir.), conviction aff'd in relevant part on rehearing en banc, 602 F.2d 653 (4th Cir. 1979) (per curiam), cert. denied, 100 S. Ct. 1647 (1980).

10 See United States v. Keane, 522 F.2d 534 (7th Cir. 1975), cert. denied, 474 U.S. 976 (1976); United States v. Isaacs, 493 F.2d 1124 (7th Cir.), cert. denied, 417 U.S. 976 (1974).

11 See United States v. Brown, 540 F.2d 364 (8th Cir. 1976); United States v. McNeive, 536 F.2d 1245 (8th Cir. 1976) (dictum); United States v. States, 488 F.2d 761 (8th Cir. 1973), cert. denied, 417 U.S. 909 (1974).

12 This development has been observed by two prior commentators. Note, A Survey of the Mail Fraud Act, 8 MEM. ST. U.L. REv. 673, 679-80 (1978); Comment, Survey of the Law of Mail Fraud, 1975 U. ILL. L.F. 237, 246-48. 
on the broad language of section $1341,{ }^{13}$ prior Supreme Court decisions, ${ }^{14}$ and other case law construing section $1341 .^{15}$

This comment addresses the question whether section 1341 properly reaches political corruption depriving citizens of their intangible rights to honest government. First, it reviews the schemes that have been held illegal under section 1341 in political-corruption cases. The comment then analyzes the statute, the legislative history, the meaning of "fraud" in the nineteenth century, and the prior case law, and concludes that section 1341 should not be read to extend to political-corruption cases.

\section{Fraudulent Schemes Involving Citizens' Intangible Rights}

United States v. Isaacs ${ }^{16}$ and United States v. Mandel ${ }^{17}$ illustrate the type of scheme involved in the intangible-rights cases. In Isaacs, the former governor of Illinois, Otto Kerner, and his close political associate, Theodore Isaacs, had been convicted under section 1341 of using the mails to defraud "the State of Illinois and its citizens of the honest and faithful services of Kerner as governor."18 The receipt of bribes provided the factual basis for the prosecution's theory of fraud..$^{19}$ Kerner, acting through Isaacs, arranged to purchase race track stock at below-market prices from the wealthy owner of Chicago-area racing interests, in return for his agreement to promote those interests before the state racing board and the state legislature. Although both Kerner and Isaacs made substantial monetary gains on their receipt of the stock, ${ }^{20}$ there was no direct monetary loss by the state on the transaction. Indeed, state revenues from horse racing actually increased during

'13 See, e.g., United States v. Mandel, 591 F.2d at 1360; United States v. States, 488 F.2d 761, 763-64 (8th Cir. 1973), cert. denied, 417 U.S. 909 (1974).

${ }^{14}$ See, e.g., United States v. Mandel, 591 F.2d at 1360; United States v. Isaacs, 493 F.2d 1124, 1150 (7th Cir.), cert. denied, 417 U.S. 976 (1974).

1s See, e.g., United States v. Mandel, 591 F.2d at 1359-62; United States v. States, 488 F.2d 761, 764-66 (8th Cir. 1973), cert. denied, 417 U.S. 909 (1974).

${ }^{18} 493$ F.2d 1124 (7th Cir.), cert. denied, 417 U.S. 976 (1974).

17591 F.2d 1347 (4th Cir. 1979). The jury convicted Mandel in 1977. The court of appeals affirmed with respect to the theory of the crime, but remanded on account of trial error. 591 F.2d 1347 (4th Cir. 1979). In a rehearing en banc, a majority of the court upheld the ruling of the trial court as to the theory of the crime, and an equally divided court affirmed the district court on the question of trial error, and so reinstated the conviction. 602 F.2d 653 (4th Cir. 1979), cert. denied, 100 S. Ct. 1647 (1980).

18493 F.2d at 1149.

19 Id. at $1146,1149$.

${ }^{20}$ Id. at 1139. 
the period in which Kerner was promoting the interests of the person from whom he had purchased the stock. ${ }^{21}$

The defendants' enrichment came directly from the person who gave them the putative bribe-a person who was neither deceived nor defrauded. ${ }^{22}$ For whatever reasons, Illinois authorities chose not to bring state charges for receiving bribes. Instead, the federal authorities-relying on the fact that Isaacs and Kerner made several mailings in connection with the scheme ${ }^{28}$-brought charges of mail fraud. To make the conduct involved fit within any arguable concept of fraud, the federal authorities had to turn to the intangible-rights theory.

The citizens of Illinois were the only persons even conceivably deceived or defrauded by the governor's conduct. ${ }^{24}$ Since they relinquished nothing of economic value, it was only by asserting that they had been deprived of certain intangible political rights that they could be called victims of any fraudulent scheme.

In United States v. Mandel, ${ }^{25}$ the defendant, Marvin Mandel, former governor of Maryland, had been convicted-along with his codefendants-under section 1341 of devising a scheme "to defraud the citizens of the State of Maryland and her governmental departments, agencies, officials and employees . . . of the right to conscientious, loyal, faithful, disinterested and honest government through bribery and non-disclosure and concealment of material information." ${ }^{26}$ Like Kerner, Mandel became the subject of federal

21 Id.

22 The race track owner who advanced the bribes, Marjorie L. Everett, was named as an unindicted coconspirator for her role in the transaction and served as a principal witness for the prosecution at the trial. Id. at 1131-32.

${ }^{23}$ For example, Isaacs and Kerner devised the pretext of a fictitious loan to make it appear as if they had purchased the stock in question four years before they really obtained it. Under this pretext, the gain they made on the stock transaction would not have appeared so abrupt and obvious. To complete the fiction, "interest" was paid on this loan, and Kerner mailed a fictitious Internal Revenue Service form to the supposed lender to notify her that she had been reported as receiving this "interest." This mailing provided the basis of one of the mail fraud counts in the indictment. Id. at 1137.

24 Id. The defendants were also convicted of "defrauding the racing associations of Illinois of the right to obtain racing dates free from corruption and bribery." Id. at 1149. But it appeared from the record that no competitor of the racing interests lost racing dates as a result of the scheme. Id. at 1139.

${ }^{23} 591$ F.2d 1347 (4th Cir.), conviction aff'd in relevant part on rehearing en banc, 602 F.2d 653 (4th Cir. 1979) (per curiam), cert. denied, 100 S. Ct. 1647 (1980).

${ }^{28} 591$ F.2d at 1359-60. The indictments also charged the defendants with "directly and indirectly" obtaining money. Id. at 1353. The court of appeals indicated, however, that it affirmed the theory of the crime in Mandel solely on the basis of the intangible-rights doctrine. Id. at 1359-60, 1359 n.6. 
criminal prosecution in connection with an alleged scheme to promote race track interests. ${ }^{27}$ In 1972 , Governor Mandel had supported certain race track legislation then in a critical stage of enactment before the Maryland General Assembly. The legislation became law, and it then became known that the law favored the interests of a group of race track investors that included friends and business associates of the governor-some of whom had given valuable personal property as well as business interests to Mandel. ${ }^{28}$ Although Mandel denied having knowledge that the legislation would favor this group, the court of appeals held that his conduct amounted to either bribery or concealment of material information and thereby constituted a violation of section $1341 .{ }^{29} \mathrm{As}$ in Isaacs, Mandel's actual enrichment was not derived directly from anyone Mandel even arguably defrauded or deceived. It was, therefore, necessary to resort to what amounts to a constructive theory of fraud, by finding that Mandel's alleged involvement in bribery and nondisclosure of material facts fraudulently deprived citizens of their right to honest government.

\section{Construction of the MaIl Fraud Statute}

Section 1341 prohibits "any scheme or artifice to defraud, or for obtaining money or property by means of false or fraudulent pretenses, representations, or promises."3o Whether this provision proscribes schemes to deprive citizens of their intangible rights as well as schemes "for obtaining money or property" depends on the meaning of "any scheme or artifice to defraud." Both the legislative history" and the meaning of the word "fraud" in the nineteenth century ${ }^{32}$ indicate that the statute only reaches schemes that have as their goal the transfer of something of economic value to the defendant.ss

${ }^{27}$ The circumstances in Mandel were far more subtle than those in Isaacs. Unlike the situation in Isaacs, all the principals in the alleged fraudulent scheme in Mandel were prosecuted, and the case against them consisted of indirect evidence. As the court of appeals stated, "It is . . . apparent that the case could not have been submitted on the theory that Governor Mandel had a direct interest in the race track business, for no direct connection on his part was either alleged or proven." Id. at 1364 .

${ }^{28}$ Mandel received some clothing for himself and jewelry for his wife. In addition, he was assigned interests in real estate. Id. at 1356-57.

29 Id. at $1360,1363,1365$.

so See note 5 supra.

31 See text and notes at notes 34-62 infra.

${ }^{32}$ See text and notes at notes 63-97 infra.

ss Most courts have concluded that the legislative history is too scanty to be of much 


\section{A. Legislative History}

1. The Origins of the Statute. The current section 1341 originated in section 301 of the Act of June 8, 1872, ${ }^{34}$ an act which consolidated and recodified the postal laws. Although it was enacted as part of a general recodification, section 301 was original legislation and had no predecessor. ${ }^{\text {ss }}$ This statute proscribed "any scheme or artifice to defraud," language which is retained in section 1341 today. $^{36}$

The postal legislation, of which the mail fraud statute constituted a part, was in large part the work of a commission appointed under congressional authority to revise and consolidate the postal laws, ${ }^{37}$ and of a committee of postal officials which then revised the Postal Code proposed by the commission. ${ }^{38}$ The Postal Code prepared by the commission did not mention "schemes to defraud." The committee of postal officials, noting this omission and concerned that contemporaneous law did not adequately protect citizens from frauds conducted through the mails, added a section to the Code so that "power [might] be given to the officers of the [post office] department to prevent the operation of lottery gamblers through the postal service." of this recommendation in section $149^{40}$ of the Act of 1872, and also enacted two other sections dealing with fraud, section $300^{41}$ and section $301,{ }^{42}$ the latter being the predecessor of the current section 1341.

The rationale for the enactment of section 301 was essentially the same as that for other antifraud provisions of the 1872 Act. The committee of postal officials, as indicated before, predicated their recommendation for new fraud legislation on the need "to prevent the frauds which are perpetrated by lottery swindlers

help in construing section 1341. See, e.g., United States v. McNeive, 536 F.2d 1245, 1248 (8th Cir. 1976).

s4 Ch. 335, § 301, 17 Stat. 323.

ss See M. Beaman \& A. McNamara, Index Analysis of the Federal Statutes, 17891873 , at 525,546 (1909).

36 See note 5 supra.

97 The commission was created by the Act of June 27, 1866, ch. 140, 14 Stat. 74 .

ss See H.R. Exec. Doc. No. 1, Pr. 3, 41st Cong., 3d Sess. 25 (1870).

30 Brief for Petitioner at 25-26, Fasulo v. United States, 272 U.S. 620 (1962) (quoting Report of Committee of Post Office Officials 19-20 (Mar. 30, 1870)).

to Act of June 8, 1872, ch. 335, § 149, 17 Stat. 302 (repealed 1909).

41 Id. $\S 300,17$ Stat. 322 (current version at 39 U.S.C. $\S 3005$ (1976)).

12 Id. $\S 301,17$ Stat. 323 (current version at 18 U.S.C. $\S 1341$ (1976)). 
through the mails"43 and drafted section 149 , which made it illegal for anyone to mail "letters or circulars concerning . . . lotteries ... or other similar . . . schemes devised . . . to deceive and defraud the public for the purpose of obtaining money under false pretences."44 Section 149, as drafted by the postal commission, reached neither the principals of the scheme nor fraudulent schemes to obtain property rather than money. ${ }^{45}$ Congress filled this gap by adding section 301 .

Section 301 reached the principals, not just those who did the mailing, in schemes described in section $149 .{ }^{46}$ It did not prohibit or restrict only fraudulent schemes involving money, as did the literal words of section 149, but was phrased in more general language to proscribe "any scheme or artifice to defraud." Congressman Farnsworth of Illinois, House sponsor of the recodification legislation, explained that sections 300 and 301 were needed "to prevent the frauds which are mostly gotten up in the large cities . . . by thieves, forgers, and rapscallions generally, for the purposes of deceiving and fleecing the innocent people in the country."47 This background suggests that Congress in the fraud legislation of 1872 did not use the term "fraud" in some new and technical way, but rather intended to prohibit schemes that were within the conventional usage of the term and involved use of the federal mails. There is, moreover, no suggestion that Representative Farnsworth intended to proscribe any form of trickery or deception other than schemes to acquire the property of others.

2. The 1889 Amendment. In 1889, Congress amended the mail fraud statute by adding specific prohibitions against schemes dealing in "green articles," "green coin," "bills," "paper goods," "spurious Treasury notes," "United States goods," or "green ci-

43 Brief for Petitioner at 25-26, Fasulo v. United States, 272 U.S. 620 (1962) (quoting Report of Committee of Post Office Officials 19-20 (Mar. 30, 1870)).

" Act of June 8, 1872, ch. 335, \& 149, 17 Stat. 302 (repealed 1909).

15 Id.

48 Section 149 provided that "it shall not be lawful to convey by mail" matter designed to promote fraudulent schemes. Id. Section 301 was aimed directly at "any person [who] devised . . . any scheme or artifice to defraud" that involved the mails. Id. § 301 .

${ }^{47}$ Cong. GLOBE, 41st Cong., 3d Sess. 35 (1870) (remarks of Rep. Farnsworth). Representative Farnsworth's remarks came during the course of debate on H.R. 2295, the recodification bill introduced in the Forty-first Congress. Failing to pass in that Congress, the recodification legislation-containing intact the sections on fraud-was reintroduced as H.R. 1 in the Forty-second Congress and was enacted into law. Act of June 8, 1872, ch. 335, 17 Stat. 283 (codified in scattered sections of 39 U.S.C. (1976)). 
gars." 48 The history of the amending legislation indicates that these terms were added at the request of postal authorities, who felt that the amendment was needed to reach certain counterfeiting schemes then prevalent. ${ }^{40}$ This amending legislation demonstrates that the original prohibition of "any scheme or artifice to defraud" was never intended to operate as a broad prohibition of all schemes to deceive. If it had been so intended, it would not have been necessary to amend the statute to reach counterfeiting schemes. The amending legislation is also important in that Congress used specific, rather than general, language to reach such schemes. A statute amended in such piecemeal fashion cannot be authority for a doctrine as expansive as that of intangible rights.

3. The 1909 Amendment. In 1909, in the course of a general revision of the federal penal code, Congress amended the mail fraud statute by adding after the original prohibition of "any scheme or artifice to defraud" the words "or for obtaining money or property by means of false or fraudulent pretenses, representations, or promises." Although this amendment is of critical importance in determining whether the mail fraud statute only reaches schemes "for obtaining money or property," the enacting Congress apparently regarded this as an unimportant modification. Congress did not even require an explanation of the change from the sponsor of the amending legislation during the course of floor debates. ${ }^{51}$

The courts applying section 1341 in intangible-rights cases have relied on the original prohibition of "any scheme . . . to defraud." They have treated that language as independent of, and broader than, the clause added in 1909. ${ }^{.2}$ These courts thus interpret the statute as proscribing two types of conduct: "schemes . . .

18 Act of Mar. 2, 1889, ch. 393, § 1, 25 Stat. 873.

$19 \mathrm{~S}$. REP. No. 2566, 50th Cong., 2d Sess. 2-4 (1889).

so Act of Mar. 4, 1909, ch. 321, § 215, 35 Stat. 1130. There were other amendments to the statute in addition to the one indicated. All are printed without explanation in S. REP. No. 10, PT. 2, 60th Cong., 1st Sess. 238-40 (1908). Only one of these other amendments has any relevance to this inquiry. This amendment added schemes dealing in "green goods" to the list of prohibitions originally set out in 1889 , see text at note 48 supra.

${ }^{31}$ See, e.g., 42 Cong. Rec. 1026 (1908) (remarks of Sen. Heyburn). In explaining the recodified and amended mail fraud statute, Senator Heyburn, the sponsor of the legislation, dealt with one change in the law affecting mailings made from outside the United States, noting: "I do not think there is any other change, which is not obvious upon the face of the bill, that needs any further explanation." Id.

B2 See, e.g., United States v. Mandel, 591 F.2d at 1360; United States v. McNeive, 536 F.2d 1245, 1247-48 (8th Cir. 1976); United States v. States, 488 F.2d 761, 763-64 (8th Cir. 1973), cert. denied, 417 U.S. 909 (1974). 
to defraud" or schemes "for obtaining money or property by means of false or fraudulent pretenses, representations, or promises."

In United States v. States, ${ }^{53}$ for example, the Court of Appeals for the Eighth Circuit ruled that the 1872 phrase and the 1909 phrase should be read "independently, rather than complementary of one another." 54 That is, the original expression "having devised or intending to devise any scheme or artifice to defraud" should be read as entirely independent of the later expression "or for obtaining money or property by means of false or fraudulent pretenses, representations, or promises," as if the two phrases were merely "part of an uninterrupted listing of a series of obviously diverse schemes." artifice to defraud" would not be modified by "for obtaining money or property." In this form, the court concluded, the original 1872 language would support a theory in which the obtaining of money or property plays no essential role. This construction of the statute should be rejected, however, since the courts that adopted it did not consider the import of a crucial piece of legislative history.

The 1909 amendment was enacted without comment or debate because it merely codified the prior Supreme Court decision of Durland v. United States. ${ }^{\mathrm{s}}$ In Durland, the Court interpreted the mail fraud statute for the first time and held inapplicable a particular common-law defense. In most jurisdictions, one could not be convicted of the crime of obtaining money or property by false pretenses if he had merely made false promises. The Supreme Court held that this defense did not apply to the federal crime of mail fraud. The key language of that decision-"some schemes may be promoted through mere representations and promises as to the future, yet are nonetheless schemes and artifices to defraud"'s7_ reappears in the language of the amendment: "representations, or promises." This change in the statute was submitted by a special commission to Congress in a modified criminal code, and the com-

s3 488 F.2d 761 (8th Cir. 1973), cert. denied, 417 U.S. 909 (1974).

s4 Id. at 764 .

ss Id. The district court in States also presented an argument for reading the two phrases independently, 362 F. Supp. 1293, 1296 (E.D. Mo. 1973), relying on United States v. Young, 232 U.S. 155 (1914). But Young stands for the proposition that there is no essential connection between the jurisdictional requirement of a mailing and the scheme to defraud. The holding of Young does not address the matter in consideration here, the relation between the 1872 phrase and the 1909 phrase, because both phrases are relevant to the fraudulent-scheme element of the crime.

ss 161 U.S. 306 (1896).

s7 Id. at 313 (emphasis supplied). 
mission cited Durland in the margin of its report next to the revised mail fraud statute. ${ }^{58}$ Thus, the 1909 amendment was designed to expand narrowly the crime of mail fraud by removing one particular common-law defense. ${ }^{59}$

Reading "any scheme ... to defraud" independently of "for obtaining money or property" strips the 1909 language of any meaning..$^{60}$ If the 1909 amendment merely lists a new and separate crime concerned with "obtaining money and property," as the Eighth Circuit suggested, then the amendment was unnecessary. The mail fraud statute had been used to prosecute crimes against property well before $1909 . .^{\circ 1}$ Moreover, reading the two phrases independently defeats Congress's aim of codifying Durland; the common-law defense, under such a reading, would be available when the defendant is prosecuted for schemes to defraud rather than for schemes to obtain money or property by false or fraudulent pretenses. If, on the other hand, one treats the insertion of the phrase "for obtaining money or property" as merely serving to illustrate what was comprehended by schemes to defraud, then the words "by means of false or fraudulent pretenses, representations, or

${ }^{68}$ See S. Doc. No. 68, Pr. 2, 57th Cong., 1st Sess. 64 (1901) (report of the Committee to Revise and Codify the Criminal and Penal Laws of the United States). See also Pearce, Theft by False Promises, 101 U. PA. L. Rev. 967, 980 (1953) (concluding that the 1909 amendment codified Durland).

s9 One possible alternate explanation was offered by Chief Justice Taft in Hammerschmidt v. United States, 265 U.S. 182, 189 (1924), discussed in text and notes at notes 125129 infra. The Chief Justice indicated that the 1909 amendment narrowed the scope of the statute after the very broad interpretation given it in Horman v. United States, 116 F. 350 (6th Cir.), cert. denied, 187 U.S. 641 (1902). Horman had extended the crime of mail fraud to reach a scheme involving pure extortion with no apparent fraud. The Chief Justice read the 1909 amendment as making it clear that the proscribed conduct must include some element of deceit or trickery. 265 U.S. at 189. This explanation is not, however, inconsistent with the thesis that the 1909 amendment codified Durland.

so Such a reading would be inconsistent with several basic principles of statutory construction. "It is the duty of the court to give effect, if possible, to every word and clause of a statute." Montclair v. Ramsdell, 107 U.S. 147, 152 (1882). See also Mastro Plastics Corp. v. NLRB, 350 U.S. 270 (1956) (Frankfurter, J., dissenting); United States v. Menasche, 348 U.S. 528, 538-39 (1955); Wilkinson v. Leland, 27 U.S. (2 Pet.) 627, 662 (1829). Another maxim of construction requires the meaning of otherwise doubtful words to be determined by reference to associated words. See, e.g., Patton v. United States, 159 U.S. 500, 509 (1895); Neal v. Clark, 95 U.S. 704, 708-09 (1877). Unless the 1909 amendment is read together with the earlier language, its meaning will be doubtful and it will be without effect-"an idle collection of words." Mastro Plastics Corp. v. NLRB, 350 U.S. 270, 297 (1956) (Frankfurter, J., dissenting). Such an interpretation is unacceptable, for " $[t]$ he cardinal principle of statutory construction is to save and not to destroy." NLRB v. Jones \& Laughlin Steel Corp., 301 U.S. 1, 30 (1937).

61 See Durland v. United States, 161 U.S. 306, 312 (1896). 
promises" apply to all schemes to defraud, and Durland was codified. Once the 1909 amendment is seen as the codification of Durland, that amendment is necessarily inconsistent with the intangible-rights theory: Congress codified Durland's interpretation of "any scheme or artifice to defraud" as applicable only to crimes against property.

Subsequent amendments to section 1341 have not affected its substance. ${ }^{62}$ The intangible-rights theory is predicated on statutory language originally drafted in 1872 and last significantly amended in 1909. Analysis of the legislative history from this period indicates that Congress intended the statute to proscribe certain crimes against property. This construction receives additional support from the meaning of the word "fraud" at the time Congress prohibited "any scheme or artifice to defraud."

\section{B. The Meaning of Fraud in the Nineteenth Century}

In the nineteenth century, the term fraud referred to a wide variety of crimes. ${ }^{63}$ Most frauds were prohibited by statute, but some were proscribed only by the common law. ${ }^{64}$ Many of those frauds prohibited by the common law in America were ones originally prohibited by English statutes. ${ }^{\text {s5 }}$ Even with respect to the frauds prohibited only by statute, courts developed so-called common-law principles of fraud as glosses upon the statutes. ${ }^{68}$

${ }_{62}$ In 1948, certain colorful words used to describe fraudulent schemes were removed. See Act of June 25, 1948, ch. 645, § 1341, 62 Stat. 763. The House Report accompanying the amending legislation noted that this change was made to delete "the obsolete argot of the underworld" and that it, together with the elimination of other language considered to be "surplusage," was effected "without change of meaning" in the statute. H.R. REP. No. 304, 80 th Cong., 1st Sess. A100 (1948). The 1949 and 1970 amendments were also of no substantive importance. See Act of May 24, 1949, ch. 139, § 34, 63 Stat. 89 ("dispose of" substituted for "dispose or"); Postal Reorganization Act, Pub. L. No. 91-375, § 6(j)(11), 84 Stat. 719 (1970) ("Postal Service" substituted for "Post Office Department").

${ }^{63}$ See generally R. Perkins, Criminal LaW 231-33, 296-98 (2d ed. 1969).

64 For example, larceny by trick was a crime at common law. See W. LAFave \& A. Scott, Handbook on Criminal Law § 85, at 627 (1972).

${ }^{6 s}$ One English statute, old enough to be part of the common law in all American jurisdictions having common-law crimes, prohibited obtaining property by means of a "false token or counterfeit letter made in any other Man's Name." 33 Hen. 8, c. 1 (1541). The English false-pretense statute, 30 Geo. 2, c. 24, § 1 (1757), was enacted in 1757 and is part of the common law in those American jurisdictions that incorporate English statutory and common law as of 1775 . See W. LAFAVE \& A. ScorT, supra note $64, \S 90$, at 655 \& nn.3-5.

${ }^{60}$ See, e.g., State v. Rowley, 12 Conn. 101 (1837) (using constructions of two English fraud statutes, 33 Hen. 8, c. 1 (1541); 30 Geo. 2, c. $24, \S 1$ (1757), as aids in construing Connecticuit false-pretenses statute); People v. Clough, 17 Wend. 351 (N.Y. Sup. Ct. 1837) (in construing the New York false-pretenses statute, court relied on English common-law 
Although courts have refused to define fraud, ${ }^{67}$ crimes of fraud have generally been regarded as crimes against property involving some form of trickery or deception. ${ }^{68}$ For example, in the nineteenth century, the prominent forms of fraud were embezzlement, false pretenses, forgery, and larceny by trick. ${ }^{69}$ Each of these. frauds was a crime against property..$^{70}$ Thus, even if the mail fraud statute's phrase "scheme . . . to defraud" proscribes all crimes encompassed by the generic term "fraud," it reaches only certain crimes against property.

It is, however, likely that the mail fraud statute uses the term "defraud" in a specific, rather than generic, sense. Indeed, the mail fraud statute should properly be interpreted as proscribing the fraud of false pretenses. The typical false-pretenses statute is al-

concepts of fraud and judicial constructions of the original false-pretenses statute, $30 \mathrm{Geo} .2$, c. 24, § 1 (1757)); People v. Stone, 9 Wend. 180 (N.Y. Sup. Ct. 1832) (using English common law and statutory law of fraud in construing state's false-pretenses statute).

Federal courts construing the mail fraud statute have considered common-law principles of fraud. See, e.g., Parr v. United States, 363 U.S. 370, 400 (1960) (Frankfurter, J., dissenting) (reference to "the common-law offense of obtaining money or goods under false pretenses"); United States v. Mandel, 591 F.2d at 1361 ("common law concepts of fraud and false pretenses").

${ }_{67}$ See Blachly v. United States, 380 F.2d 665, 671 (5th Cir. 1967); Gregory v. United States, 253 F.2d 104, 109 (5th Cir. 1958); Weiss v. United States, 122 F.2d 675, 681 (5th Cir.), cert. denied, 314 U.S. 687 (1941); Foshay v. United States, 68 F.2d 205, 211 (8th Cir. 1933), cert. denied, 291 U.S. 674 (1934).

${ }^{\text {es }}$ See $1 \mathrm{~J}$. Bishop, Commentaries on the Criminal Law $\$$ 565-590 (7th ed. 1882) (major fraudulent crimes are classified as crimes against property); 2 W. Russent, Russell ON CrIME 1203-1501 (11th ed. J. Turner 1958) (all major crimes of fraud are listed as "offenses against property"); 2 J. Stephen, A History of the CRiminal Law of England 12122 (1883) (referring to fraud as "either actual injury or possible injury . . . by means of . . . deceit or secrecy" in a context of economic crimes). See also Fridman, Intent to Defraud Reconsidered, 1960 CRIM. L. REv. 530, 537-38 (explaining economic context of Stephen's characterization of fraud).

- See, e.g., 2 J. Bishop, New Commentaries on the Criminal Law $\$ \S 318-383$, at 182 220 (8th ed. 1892) (embezzlement); id. $\$ \S 409-488$, at 235-79 (false pretenses); id. §§ 521612, at 300-48 (forgery); C. Kenny, Outuines of Criminal Law 206 (1902) (larceny by trick); id. at 228-39 (embezzlement); id. at 240-51 (false pretenses); id. at 255-63 (forgery); $2 \mathrm{~W}$. Russell, A Treatise on Crimes and Misdemeanors 1131-51 (R. Ross \& G. McClure eds. 1923) (larceny by trick); id. at 1304-32 (embezzlement); id. at 1400-78 (false pretenses); id. at $1505-91$ (forgery).

30 See Primrose v. Western Union Tel. Co., 154 U.S. 1, 14 (1894) (dictum) (embezzlement); 2 J. Bishop, supra note 68, $\S 325$, at 186-87 (embezzlement); 2 W. Russelr, supra note 68, at 1048-82 (larceny by trick); $i d$. at 1277-83 (embezzlement); id. at 1421-23 (forgery); 2 F. Wharton, Wharton's Criminal Law § 915, at 1219-20 (12th ed. J. Ruppenthal 1932) (forgery); text and notes at notes 76-80 infra (false pretenses). Because forgery was an inchoate crime, it was not necessary that the forger succeed in obtaining something of value. See 2 J. Bishop, supra note 69, § 524, at 301-02. 
most identical to section 1341 as amended in $1909 .{ }^{71}$ In addition, the Supreme Court, ${ }^{72}$ other courts, ${ }^{73}$ and commentators ${ }^{74}$ have treated the mail fraud statute as one proscribing the fraud of false pretenses. This narrower construction is consistent with the maxim that criminal statutes should be narrowly construed and saves the statute from a possible constitutional attack on vagueness grounds. ${ }^{78}$

During the period of enactment and critical amendment of the mail fraud statute, it was impossible to obtain a conviction for false pretenses unless the defendant had directly received something of economic value from the victim of the supposed fraudulent scheme. Moreover, those decisions permitting convictions for fraud although the victim had suffered no economic loss were not inconsistent with the general requirement that the victim transfer something of economic value to the defendant.

71 See, e.g., Mass. GEN. STAT. ch. 161, $\$ 54$ (1860) ("Whoever designedly, by a false pretense . . . with intent to defraud, obtains from another person any property"); Mo. REv. STAT. ch. 36, § 4565 (1909) ("Every person who . . . shall designedly . . . by any . . . false pretense . . . obtain from any person any money, personal property . . . or other valuable thing"); N.Y. REv. STAT. pt. 4, ch. 1, tit. 3, § 58 (1875) ("Every person who, with intent to cheat or defraud another, shall designedly . . . by any . . . false pretense . . . obtain from any person any money, personal property, or valuable thing"). See also 30 Geo. 2, c. $24, \S 1$ (1757) (the original English false-pretenses statute, which is part of the common law in some American jurisdictions) ("all persons who knowingly and designedly, by false pretence or pretences, shall obtain from any person or persons, money, good, wares, or merchandizes, with intent to cheat or defraud any person or persons of the same . . . shall be . . . fined and imprisoned").

72 See Durland v. United States, 161 U.S. 306 (1896) (implicity treating the mail fraud statute as a false-pretenses statute).

73 See, e.g., People v. Ashley, 42 Cal. 2d 246, 261 n.3, 267 P.2d 271, 281 n.3 (1954) (Traynor, J.) (using the U.S. Supreme Court's construction of the mail fraud statute in Durland as an aid in construing the California false-pretenses statute).

74 See, e.g., F. Inbau, J. Thompson \& A. Moenssens, Cases and Comments on Criminal LAw 595-600 (1973) (mail fraud statute is presented in same section as false pretenses); W. LAFAve \& A. ScoTr, supra note $64, \S 90$, at 671 (mail fraud statute presented as a crime related to false pretenses); R. PERKINS, supra note 63, at 297 n.6; Pearce, supra note 58, at 979.

${ }^{75}$ For instance, if the statute is not limited by any common-law fraud principles, thus proscribing all conduct considered contrary to public policy and morals by the courts, see Mandel, 591 F.2d at 1360-61, it might be struck down as unconstitutional. In United States v. L. Cohen Grocery Co., 255 U.S. 81 (1921), the Supreme Court struck down a federal criminal statute on void-for-vagueness grounds. This action, however, was exceptional because the Court has seldom struck down a federal statute as unconstitutional for vagueness. See Note, The Void-For-Vagueness Doctrine in the Supreme Court, 104 U. PA. L. Rev. 67, $83 \mathrm{n} .80$ (1960). "[The] Court has consistently favored that interpretation of legislation which supports its constitutionality. . . . Only if no construction can save the Act [in question] from [the] claim of unconstitutionality are we willing to reach that result." Screws v. United States, 325 U.S. 91, 98, 100 (1945). 
1. The American Cases Involving Statutes Proscribing the Fraud of False Pretenses. In 1907, in the decision of In re Waterman, ${ }^{76}$ the Supreme Court of Nevada enunciated what had been an accepted principle of law for at least the preceding half century: "The obtaining and possession of something of value is an essential ingredient of the crime of obtaining money, goods or other property, under false pretenses, and where this essential ingredient is lacking, there is no crime."77 Waterman involved a habeas corpus proceeding in which a man held in custody by Nevada authorities challenged the sufficiency of his indictment for false pretenses in Iowa, whose officials were seeking his extradition. The Nevada court carefully analyzed the formal indictment against Waterman, comparing it with the requirement of the Iowa false-pretenses statute. ${ }^{78}$ The court found the indictment "fatally defective" because it failed to allege that Waterman had received anything of value from the victim in connection with the alleged scheme to defraud, and accordingly granted the writ. ${ }^{79}$

Commonwealth v. Harkins ${ }^{80}$ illustrates the lengths to which courts went in preserving the requirement that the defendant obtain some tangible thing of value. The defendant, by falsely asserting that he had sustained personal injuries for which the victim of the deception bore responsibility, obtained a consent judgment against the victim. The court ruled that the judgment could not serve as the basis for a conviction for false pretenses because the defendant had received money only after the order had been entered. The entry of the order marked the termination of the scheme and payment afterwards under the order was entirely lawful. ${ }^{81}$

Some nineteenth-century courts permitted convictions for false pretenses although the victim suffered no economic loss.

70 29 Nev. 288, 89 P. 291 (1907).

77 Id. at 299, 89 P. at 295 (citing Jamison v. State, 37 Ark. 445 (1881)). Accord, Connor v. State, 29 Fla. 445, 10 So. 891 (1892); State v. Clark, 72 Iowa 30, 33 N.W. 340 (1887); State v. McGinnis, 71 Iowa 685, 33 N.W. 338 (1887); State v. Anderson, 47 Iowa 142 (1877); State v. Lewis, 26 Kan. 123 (1881); Bracey v. State, 64 Miss. 26, 8 So. 165 (1886); Willis v. People, 26 N.Y. Sup. Ct. 84 (App. Div. 1879).

${ }^{78}$ Iowa CoDE ANN. $\$ 5041$ (West 1897) ("If any person designedly and by false pretense, . . . with intent to defraud, obtain from another any money, goods or other property, ... he shall be imprisoned . . . or . . . fined"), quoted in In re Waterman, $26 \mathrm{Nev.} \mathrm{288,}$ 297-98, 89 P. 291, 294-95 (1907).

29 29 Nev. at 298-300, 89 P. at 295.

so 128 Mass. 79 (1880).

si Id. at 82-83. Such payment was in fact a legal obligation. 
These decisions, however, are not inconsistent with the requirement that the victim transfer something of economic value to the defendant. In LaMoyne v. State, ${ }^{82}$ the Texas Court of Criminal Appeals affirmed the conviction of a farmer who had been accused of swindling ${ }^{83}$ a merchant of certain machinery. The farmer had obtained the machinery on credit by granting the merchant a mortgage on his crops and farm-a transaction to which the merchant agreed only after the farmer falsely represented that there were no liens on his property. Since the farmer had retained sufficient equity in the property to secure fully his debt to the merchant, the merchant was able to recover the machinery and sell it without any apparent loss. The court found that the lack of any economic loss to the merchant would not serve as a defense to swindling. ${ }^{84}$ Rather, the court found that the crime is determined by "the value of the property the possession of which is so fraudulently acquired."

People v. Bryant ${ }^{86}$ was a similar case. The defendant had sold to the victim a promissory note secured by a mortgage, but only after the defendant had falsely represented that the land covered by the mortgage was "good, tillable land, of good soil and of great value." gage served only to secure the note, and since it had not been shown that the maker of the note would not fulfill his obligation, the "indictment fail[ed] to show that [the victim had] been defrauded of any of her property." held, however, that "[i]f a person is induced to part with his property by reason of fraudulent pretenses and misrepresentations, he is thereby defrauded of the property so parted with, even though he may eventually make himself whole in some mode not then

${ }^{82} 53$ Tex. Crim. 221, 111 S.W. 950 (Crim. App. 1908).

${ }^{83}$ The crime of false pretenses is known as "swindling" in Texas. See W. LAFave \& A. ScoTt, supra note $64, \S 90$, at 655 n.2.

${ }^{84} 53$ Tex. Crim. at 224, 111 S.W. at 950. In denying a motion for rehearing, the court explicitly overruled three of its own previous decisions holding that lack of economic loss was a defense to the crime. Id. at 225-30, $111 \mathrm{~S}$.W. at 951-54.

${ }^{8 s}$ Id. at $229,111 \mathrm{~S} . \mathrm{W}$. at 953 . The defendant had been convicted of misdemeanor swindling-a crime limited to amounts under $\$ 50$. In dictum, the appellate court noted that he should have been charged with felony swindling, since the value of the farm machinery obtained was in excess of $\$ 50$. Id. at $224,111 \mathrm{~S}$.W. at 950 .

${ }^{86} 119$ Cal. 595, 51 P. 960 (1898).

${ }^{87} I d$. at $596,51 \mathrm{P}$. at 960 .

${ }^{88}$ Id. at 597,51 P. at 961 . 
contemplated." ${ }^{\prime 8}$

LaMoyne and Bryant thus stand for the proposition that a conviction for the fraud of false pretenses can be sustained even when the victim has suffered no economic loss. ${ }^{90}$ The cases do not signal, however, a departure from the requirement that something of economic value be obtained from the victim. In LaMoyne, the defendant acquired farm machinery from the victim; in Bryant, the money paid for the promissory note.

2. The English Case Law. In construing the English falsepretenses statute, ${ }^{\text {,1 }}$ the English courts have consistently required that the defendant receive something of economic value from the victim. ${ }^{92}$ For example, in Rex $v$. Wavell, ${ }^{93}$ the court held that the defendant could not be convicted for a scheme in which he acquired credit from a bank. Although the defendant's creditors had benefited from the transaction, the defendant had not received any money, chattel, or other item of value. The court ruled that the extension of credit alone did not, therefore, fall within the ambit of the statute. ${ }^{94}$

so Id.

- For cases addressing the relevance of economic loss, see, for example, Commonwealth v. Ferguson, 135 Ky. 32, 121 S.W. 967 (1909); State v. Miller, 212 Mo. 73, 111 S.W. 18 (1908) (dictum); People v. Cook, 48 N.Y. Sup. Ct. 67 (App. Div. 1886). See also cases cited in Annot., 53 A.L.R.2d 1215 (1957).

11 The false-pretenses statute construed by the cases considered here read, in part: "[I]f any Person shall by any false Pretence obtain from any other Person any Chattel, Money, or valuable Security, with Intent to cheat or defraud any Person of the same, every such Offender . . . shall be liable . . . to be transported beyond the Seas for the Term of Seven Years." $7 \& 8$ Geo. 4, c. 29, § 53 (1827).

${ }^{92}$ In a decision under a forgery statute, Welham v. Director of Pub. Prosecutions, [1961] A.C. 103, the House of Lords faced a problem of statutory interpretation similar to the one in this inquiry. In construing the Forgery Act of 1913, 3 \& 4 Geo. 5, c. 27, the Lords were called upon to decide whether the substance of defrauding consists of mere deceit, or deceit with the intent to cause economic loss. The question was resolved by finding that the concept of fraud had not been confined to the causing of economic loss since at least the mid-nineteenth century. [1961] A.C. at 124 (Lord Radcliffe), 131 (Lord Denning). But their decision had no impact on the line of cases requiring the acquisition of something of value from the victim, for the issue before the House was not framed in terms of this quite separate question.

${ }^{93} 1$ Mood. 224, 168 Eng. Rep. 1249 (K.B. 1829).

or Id. at 230, 168 Eng. Rep. at 1252. Regina v. Garrett, 1 Dears. C.C. 232, 169 Eng. Rep. 707 (K.B. 1853), is another case in which the statute was strictly construed. The defendant, an international traveler, received money on a forged letter of credit from the branch of a British financial firm in Russia, and this firm in turn sought reimbursement from another bank in London on the basis of the second bank's obligations under the letter of credit. The defendant was convicted of false pretenses for defrauding the second bank in London. Lord Campbell did not, however, allow the conviction to stand, since the defendant received nothing from the second bank. The false pretense was made to the second bank, but the 
In Regina $v$. Eagleton, ${ }^{85}$ the defendant received a credit on account for goods he knew to be defective. In affirming the conviction for attempting to obtain money under false pretenses, the court noted that the defendant had not yet received actual payment, and thus could not be convicted of the crime of obtaining something under false pretenses. ${ }^{96} \mathrm{He}$, too, had received nothing of value from his victim.

Thus, the legislative history of the statute and the contemporaneous understanding of fraud indicate that the scheme or artifice to defraud is a scheme or artifice to trick the victim into transferring something of economic value to the defendant. When corrupt politicians deprive citizens of their intangible rights to honest government, there may be deception, but there is no transfer of anything of economic value ${ }^{97}$ from the citizens to the politician. The meaning of fraud at the time the mail fraud statute was enacted and initially amended does not, therefore, support the intangiblerights theory.

\section{Support for the Intangible-Rights Doctrine in Prior Federal Case Law}

Although the legislative history of the statute and the nineteenth-century understanding of "fraud" fail to support the intangible-rights doctrine, decisions of the Supreme Court and of several courts of appeals have been cited as support for the doctrine. These cases have been misapplied, however, when offered as authority for the doctrine.

\section{A. Supreme Court Decisions}

Although the Supreme Court has not dealt directly with the

money was received from the first bank. "A gross fraud has been committed, but not an obtaining money under false pretences within the statute." Id. at 241, 169 Eng. Rep. at 711. The prosecution of the defendant in this case resembles prosecutions for political corruption based on the intangible-rights theory in that an unlawful acquisition of money from one firm or person was used in an attempt to secure a conviction for defrauding a second firm or person, from whom no money was directly received. Lord Campbell did in fact condemn the original underlying conduct of the defendant in this case, but he clearly distinguished it from conduct that was within the reach of the statute.

9s 1 Dears. C.C. 515, 169 Eng. Rep. 826 (Q.B. 1855).

96 Id. at 537-38, 169 Eng. Rep. at 835-36.

${ }^{87}$ In Carey v. Piphus, 435 U.S. 247 (1978), the Supreme Court, in an action for damages under section 1983 of Title 42 of the United States Code, held that constitutionally guaranteed civil rights have no intrinsic economic value. Id. at 254-55. 
intangible-rights doctrine, ${ }^{98}$ two Supreme Court decisions construing section 1341, Durland v. United States ${ }^{98}$ and Badders $v$. United States, ${ }^{100}$ and Supreme Court cases analyzing fraud in federal statutes other than section 1341, have been cited as support for the intangible-rights doctrine. ${ }^{101}$

1. Durland v. United States. As discussed above, the principal issue in Durland was whether the common-law defense of false promises might prevent a conviction under the mail fraud statute. ${ }^{102}$ Under the majority rule at common law during the nineteenth century, a conviction for false pretenses could not be obtained on the basis of a false promise; a false representation had to refer to an existing or past fact to provide the basis for a conviction. ${ }^{103}$ The Supreme Court held that this defense was not available in prosecutions under the mail fraud statute: "The statute is broader than is claimed. Its letter shows this: 'Any scheme or artifice to defraud.' Some schemes may be promoted through mere representations and promises as to the future, yet are none the less schemes and artifices to defraud."104

The Durland Court's reference to the breadth of the statute has led some lower courts to interpret Durland as eliminating all common-law principles of fraud in connection with section $1341 .{ }^{105}$

98 The only section 1341 political-corruption case to reach the Supreme Court is Parr v. United States, 363 U.S. 370 (1960). The defendant in Parr was acquitted because of the prosecution's failure properly to demonstrate use of the mails, and the Court did not address the validity of the intangible-rights doctrine. Id. at 393-94.

161 U.S. 306 (1896).

100240 U.S. 391 (1916).

101 See text and notes at notes 113-137 infra.

102 See text and notes at notes 56-59 supra. The defendant in Durland had devised a scheme to inveigle persons to "invest" in certain bonds that he promised would mature in extraordinarily short periods of time, producing very handsome profits for the putative "investors." The defendant's intention was to take all the money realized in the scheme for himself, paying nothing to the victims. Counsel for the defendant argued that his conviction for mail fraud could not stand, primarily on the ground that the defendant had made no representation as to existing fact but only a false promise about the future. 161 U.S. at 31214.

103 See, e.g., Commonwealth v. Drew, 36 Mass. (19 Pick.) 179 (1837); Rex v. Goodhall, Russ. \& R. 461, 168 Eng. Rep. 898 (K.B. 1821); F. Whatton, A Treatise on the Criminal LAW OF THE UNITED States 543 (Philadelphia 1846).

104161 U.S. at 313.

105 See, e.g., United States v. Mandel, 591 F.2d at 1361; United States v. States, 488 F.2d at 761, 764 (8th Cir. 1973), cert. denied, 417 U.S. 909 (1974). But see United States v. Rowe, 56 F.2d 747, 749 (2d Cir.), cert. denied, 286 U.S. 554 (1932) (L. Hand, J.) (Durland limited to removal of the false-promises defense only). In Parr v. United States, 363 U.S. 370 (1960), discussed in note 98 supra, Justice Frankfurter, in dissent, interpreted Durland as eliminating all common-law defenses. 363 U.S. at 400-01. 
In so doing, these courts apparently disregard the fact that Durland eliminated a single common-law defense. The Court did not hold that all common-law principles of fraud were inapplicable to section $1341 .^{106}$ Indeed, the Court was faced with no issue having a direct bearing on the intangible-rights doctrine. ${ }^{107}$ Both after its ruling in the case and after the congressional codification of the ruling, the transfer of money or property was required in prosecutions under the statute. ${ }^{108}$

2. Badders v. United States. Badders ${ }^{109}$ has been cited as support for a broad reading of the statute in the political-corruption cases. ${ }^{110}$ In United States $v$. Mandel, for example, the Fourth Circuit cited Badders dictum to support the proposition that section 1341 prohibits all forms of deception contrary to "accepted moral standards and notions of honesty and fair play."111 Although the Supreme Court stated that section 1341's jurisdiction over misconduct accomplished through the mails provided a basis for Congress to proscribe anything contrary to public policy, the Court in Badders did not hold that Congress had done so. ${ }^{112}$ The issue in that case was the constitutional question whether congressional power to regulate the mails necessarily included the power to punish certain conduct as criminal. The Court did not construe the concept of fraud in section 1341 broadly; rather, it construed broadly the constitutional power of Congress. Properly understood, the Badders dictum provides no support for the intangible-rights doctrine.

\section{Supreme Court Interpretations of Fraud in Other Federal}

${ }^{108}$ In United States v. McNeive, 536 F.2d 1245, 1247 n.3 (8th Cir. 1976), the Eighth Circuit considered Durland relevant to the intangible-rights theory because Durland recognized that the definition of fraud in the mail fraud statute was intended by Congress to be broader than the definition of fraud recognized at common law. Such reasoning, however, equates the removal of one common-law restriction with the removal of all such restrictions.

${ }_{10 z}$ The Court did decide a subsidiary issue involving the mailing requirement. 161 U.S. at 314-15. In the course of resolving this issue, the Court stated in dictum that "[i]t is enough if, having devised a scheme to defraud, the defendant with a view of executing it deposits in the post office letters, which he thinks may assist in carrying it into effect, although in the judgment of the jury they may be absolutely ineffective therefor." Id. at 315 . The reference of the Court here was to the fact that the defendant's actions involved an attempted fraud. Id. at 309,310 . Despite its lack of success, there is no doubt that the fraudulent scheme of the case involved the obtaining of money.

${ }^{108}$ See text and notes at notes 56-61 supra.

${ }^{109}$ Badders v. United States, 240 U.S. 391 (1916).

${ }_{110}$ E.g., United States v. Mandel, 591 F.2d at 1360; United States v. States, 488 F.2d 761, 767 (8th Cir. 1973), cert. denied, 417 U.S. 909 (1974).

111591 F.2d at 1360.

112 Badders v. United States, 240 U.S. 391, 393 (1916). 
Statutes. The other Supreme Court cases cited by the lower federal courts as support for the intangible-rights doctrine concern the meaning of fraud in various federal statutes. In intangiblerights cases under section 1341, the issue is whether a conviction is possible without the transfer of valuable property. In the cited cases, however, there had either been such a transfer or the conviction was not sustained.

The court in United States v. Isaacs cited Supreme Court cases decided under two other federal statutes to support the intangible-rights doctrine. United States $v$. Barnow ${ }^{\mathbf{1 1 3}}$ involved a prosecution under a statute making it a federal crime falsely to "assume or pretend to be an officer or employee . . . of the United States ... [and] in such pretended character demand or obtain from any person . . . any money, paper, document, or other valuable thing," with intent to defraud.114 The victims had transferred money to the defendant, but sustained no economic loss. ${ }^{115}$ The Court ruled that economic loss was unnecessary for conviction. This case-like LaMoyne $e^{118}$ and Bryant ${ }^{117}$-is, however, only another illustration of the common-law principle that the victim need not suffer economic loss provided the defendant has received something of economic value from the victim.

The Seventh Circuit, in Isaacs, cited two other Supreme Court cases as support for the intangible-rights theory: Hass $v$. Henkel, ${ }^{118}$ and Hammerschmidt $v$. United States. ${ }^{119}$ Each of these cases was decided under a predecessor to section 371 of Title 18, that proscribed any conspiracy "to defraud the United States . . . in any manner or for any purpose."

In Haas, the Court upheld an indictment charging the prisoner, who was seeking habeas corpus relief, with defrauding the government. ${ }^{121}$ The Court noted that the statute reached conspiracies "to defraud the United States by depriving it of its lawful right ... of promulgating or diffusing ... information . . . offi-

113239 U.S. 74 (1915).

134 Act of Mar. 4, 1909, ch. 321, § 32, 35 Stat. 1088 (current version at 18 U.S.C. $\S 912$ (1976)).

118239 U.S. at 75.

118 See text and notes at notes $82-85$ supra.

117 See text and notes at notes 86-89 supra.

118216 U.S. 462 (1910).

110265 U.S. 182 (1924).

120 Rev. Stat. $\$ 5440$ (1878) (current version at 18 U.S.C. $\$ 371$ (1976)). Since the crime was defined to include conspiracy, inchoate fraud could be punished under this provision.

121216 U.S. at $479-80$. 
cially acquired."122 The Court added, however, that "it is not essential to charge or prove an actual financial or property loss to make a case under the statute." 123 The statement is merely a repetition of the common-law rule that pecuniary loss by the victim is unnecessary as long as the requirements of fraud have been met.124

The Isaacs court relied on the Supreme Court decision of Hammerschmidt $v$. United States by quoting the following passage: "It is not necessary that the Government shall be subjected to property or pecuniary loss by the fraud, but only that its legitimate official action and purpose shall be defeated by misrepresentation, chicane or the overreaching of those charged with carrying out the governmental intention." ${ }^{125}$ The Seventh Circuit did not explain how this statement supported the intangible-rights doctrine. ${ }^{126}$ The first clause of the quoted sentence merely repeats the common-law principles that the victim of a fraud need not suffer economic loss.

The second clause of the quoted statement arguably supports the intangible-rights doctrine. The Court, it might be argued, used the words, "but only that its legitimate official action and purpose shall be defeated by," to indicate that a transfer of something of economic value is unnecessary whenever the interference with official government action has resulted in a deprivation of rights. Such an argument is, however, untenable. There are two elements to fraud: deception and the transfer of an item of economic value. ${ }^{127}$ The question before the Court, noted Chief Justice Taft, was "whether deceit or trickery was essential to satisfy the defrauding required under the statute,"128 and it was to that question that the quoted statement was undoubtedly addressed. Indeed, the con-

122 Id.

${ }^{123}$ Id. at 480 .

124 The cases the Haas Court cited also provide no support for the intangible-rights doctrine. Both cases were decided under the predecessor to section 371 of Title 18 . Hyde v. Shine, 199 U.S. 62 (1905), dealt with a purported scheme to defraud the government in a transaction concerning public lands. This case, like Haas, held that the victim of a fraudulent scheme need sustain no economic loss. Id. at 81-82. It is, moreover, clear that the defendants in Hyde received something of value-public lands. Id. at 83. United States v. Keitel, 211 U.S. 370 (1908), involved a scheme to defraud the government of title to certain coal lands. Again the Court found the lack-of-economic-loss argument to be unpersuasive, and ruled against the defendant. Id. at 393-94.

${ }_{125}$ United States v. Isaacs, 493 F.2d 1124, 1150 (7th Cir.), cert. denied, 417 U.S. 976

(1974) (quoting Hammerschmidt, 265 U.S. at 188).

128 See id.

${ }^{127} 2 \mathrm{~J}$. STEPHEN, supra note 68, at 121-22; Fridman, supra note 68, at 537-38.

${ }^{128}$ Hammerschmidt v. United States, 265 U.S. 182, 187 (1924). 
cluding words of the second clause specify that the statute required only that official action be defeated by "misrepresentation, chicane or overreaching"-language plainly discussing the deception requirement. ${ }^{128}$

Thus, the Supreme Court cases cited by the Seventh Circuit in Isaacs either fail to support or undercut the intangible-rights doctrine. Other courts, however, have attempted to support the doctrine with Supreme Court precedent. In United States v. States, ${ }^{130}$ for instance, the federal district court cited two Supreme Court decisions for the proposition that the intangible rights of citizens to representative government have economic value and that "[u]nder our form of government . . . it could hardly be contended that the right to have one's vote counted, undiluted by fraudulent absentee ballots, is without value."131

The States court relied on United States $v$. Saylor ${ }^{132}$ and United States $v$. Classic. ${ }^{133}$ Both cases involved federal prosecutions for interference with the conduct of elections, and were brought under a Reconstruction-era civil rights statute making it a criminal offense for "two or more persons [to] conspire to injure . . . any citizen in the free exercise or enjoyment of any right . . . secured to him by the Constitution or laws of the United States."194 The issue in both cases was whether the statute could be construed to prohibit certain specific kinds of election irregularities, in a context in which citizens' voting rights were acknowl-

120 See id. at $185-87$.

The Hammerschmidt Court cited several of its prior decisions in the opinion, and-like Hammerschmidt itself-none of these cases provides support for the intangible-rights theory. See United States v. Barnow, 239 U.S. 74 (1915); United States v. Foster, 233 U.S. 515 (1914); United States v. Plyler, 222 U.S. 15 (1911); Haas v. Henkel, 216 U.S. 462 (1910), discussed in text and notes at notes 121-123 supra. In Foster, brought under the Act of Mar. 4, 1909, ch. 321, § 37, 35 Stat. 1096 (current version at 18 U.S.C. $\S 371$ (1976)), the Court found that although the Government might well have suffered no economic loss in the fraudulent transaction, there were grounds for charging the defendant with criminal conduct. 233 U.S. at 525-26. The defendant postmaster meant to obtain a thing of value through his conspiratorial action: an increase in his salary. Id. at 519-20.

1s0 362 F. Supp. 1293, aff'd, 488 F.2d 761 (8th Cir. 1973), cert. denied, 417 U.S. 909 (1974).

131 Id. at 1296.

${ }^{132} 322$ U.S. 385 (1944).

135313 U.S. 299 (1941).

134 18 U.S.C. § 241 (1976). Classic also involved the predecessor to 18 U.S.C. $\S 242$ (1976). The district court decision in United States v. Classic, 35 F. Supp. 457 (E.D. La. 1940), did contain a ruling that the defendants might be prosecuted under the mail fraud statute for their role in voting irregularities, but this issue was not preserved for decision by the Supreme Court. 
edged to be constitutionally protected. ${ }^{195}$ The cases do not support the proposition that intangible civil rights have economic value $^{136}$ - a proposition of dubious validity today ${ }^{137}$ and undoubtedly beyond the intentions of Congress in 1872, when the mail fraud statute was first enacted. The presentation of Supreme Court authority by the lower courts has been inapposite because these courts have ignored the explicit requirements for a finding of fraud. The central requirement-the transfer of something of economic value-has not been discarded by prior Supreme Court decisions.

\section{B. Decisions of the Lower Federal Courts}

The courts that have adopted the intangible-rights doctrine have relied ${ }^{188}$ on the earlier decisions of two lower courts: Shushan $v$. United States, ${ }^{139}$ decided by the Fifth Circuit in 1941, and United States $v$. Procter \& Gamble Co., ${ }^{140}$ decided by a district court in 1942. Careful analysis of these cases reveals, however, that although the defendants were charged with participation in schemes involving the breach of certain rights and duties, they also derived direct financial benefit from the victims of their frauds. These cases do not provide authority for the intangible-rights theory, under which there is no requirement that the defendant receive something of economic value from the victims of the fraud.141

In Shushan, the codefendants sought to obtain by fraud money from the parish fisc. Abraham Shushan, who had previously served on the Orleans Parish Levee Board, ${ }^{142}$ conspired with a current Board member and three others in a scheme by which they obtained money deceptively from the Board through a plan to re-

${ }^{283}$ United States v. Classic, 313 U.S. 299, 307-29 (1941); United States v. Saylor, 322 U.S. 385, 387-88 (1944). Justice Douglas, dissenting in Saylor, focused especially on the issue of federalism. Id. at 390-93 (Douglas, J., dissenting).

${ }^{136}$ Cf. United States v. Gradwell, 243 U.S. 476, 481, 485 (1917) (a conspiracy to bribe electors does not constitute a fraud upon the United States) (decided under Act of Mar. 4, 1909 , ch. 321, § 37, 35 Stat. 1096 (current version at 18 U.S.C. $\$ 371$ (1976))).

${ }_{137}$ See text and note at note 97 supra.

138 See, e.g., United States v. Mandel, 591 F.2d at 1362; United States v. Isaacs, 493 F.2d 1124, 1149-50 (7th Cir.), cert. denied, 417 U.S. 976 (1974); United States v. States, 488 F.2d 761, 766 (8th Cir. 1973), cert. denied, 417 U.S. 909 (1974).

${ }^{139} 117$ F.2d 110 (5th Cir. 1941), cert. denied, 313 U.S. 574 (1942).

14047 F. Supp. 676 (D. Mass. 1942).

${ }^{141}$ See text and notes at notes 8-12 supra.

142 He had been appointed by the late Governor and U.S. Senator Huey Long. T.H. Williams, Huey Long 421 (1969). 
fund outstanding issues of its bonds. The defendants charged an exorbitant fee for the refunding service subsequently rendered; the fee was divided among the defendants according to a prearranged formula. ${ }^{143}$ The Fifth Circuit noted that "all [of the defendants' conduct] was done and intended to obtain sums of money from the Board and taxpayers to be converted to [the defendants' own] use."144 This aspect of Shushan plainly provides no support for the intangible-rights doctrine.

Another part of the Shushan opinion-concerned with demonstrating the requisite element of deception-has, however, been cited as support for the intangible-rights doctrine. To strengthen its contention that the convictions did not rest solely on false representations or lies about the nature of the funding scheme, the court invoked a theory of fraud predicated on breach of fiduciary duty. ${ }^{145}$ The one defendant sitting on the Board was bribed by the other defendants to persuade the Board to agree to the refunding scheme. The defendant Board member did so without revealing his own private interest in the matter. These actions by all the defendants resulted in a breach of their fiduciary duty to the Board and to the public. As the court stated, "No trustee has more sacred duties than a public official and any scheme to obtain an advantage by corrupting such an one [sic] must in the federal law be considered a scheme to defraud." 146 Separating the words from their context, the statement might seem to support the intangiblerights doctrine; accordingly, some courts have cited Shushan in support of the doctrine. ${ }^{147}$ The context, however, demonstrates that the court was not addressing the question whether the defendants gained in the scheme; the court had already concluded that the economic requirement had been met. ${ }^{148}$ Rather, the court was

\footnotetext{
143 117 F.2d at $114-15$

146 Id. at 115.

145 Id.

246 Id.
}

147 See, e.g., United States v. States, 488 F.2d 761, 766 (8th Cir. 1973) ("In Shushan there is the implication that a scheme to gain personal favors from public officials is a scheme to defraud the public, although the interest lost by the public can be described no more concretely than an intangible right to the proper and honest administration of government"), cert. denied, 417 U.S. 909 (1974). Accord, United States v. Keane, 522 F.2d 534, 546 (7th Cir. 1975); United States v. Isaacs, 493 F.2d 1124, 1150 (7th Cir.), cert. denied, 417 U.S. 976 (1974).

148 Only a few lines earlier, the court noted that "[a] scheme to get money unfairly by obtaining and then betraying the confidence of another ... . would be a scheme to defraud though no lies were told." 117 F.2d at 115 (emphasis added). 
establishing the proposition that breach of fiduciary duty is a kind of deception, and that when such a breach accounts for the acquisition of money-as it did here-the defendants have committed fraud.

United States v. Procter \& Gamble Co. ${ }^{149}$ involved a prosecution under section 1341 in a nonpolitical setting. The corporate defendant had bribed employees of a competitor to obtain certain trade secrets of the competitor. The court explicitly rejected the defendant's contention that the proprietary information it illicitly obtained lacked monetary value. ${ }^{150}$ Like the Fifth Circuit in Shushan, the court went on to consider whether the defendant had used deception, and, as in Shushan, the court's theory involved breach of fiduciary duty: "When one tampers with that relationship [between employer and employee] for the purpose of causing the employee to breach his duty he in effect is defrauding the employer of a lawful right."151 Although Procter \& Gamble has been cited as support for the intangible-rights doctrine by many of the recent political-corruption cases ${ }^{152}$ and by two recent Seventh Circuit cases adopting the doctrine in a corporate context, ${ }^{163}$ the Procter \& Gamble court did not embrace any theory of intangible rights. Rather, the court held that something of economic valueproprietary information-had been taken from the defendant.

Procter \& Gamble and Shushan establish no more than that

1497 F. Supp. 676 (D. Mass. 1942).

160 Id. at 679.

18s Id. at 678.

${ }^{162}$ See, e.g., United States v. States, 488 F.2d 761, 766 (8th Cir. 1973) cert. denied, 417 U.S. 909 (1974); United States v. Mandel, 415 F. Supp. 997, 1012 (D. Md. 1976), rev'd on other grounds, 591 F.2d 1347 (4th Cir.), conviction aff'd in relevant part en banc, 602 F.2d 653 (4th Cir. 1979) (per curiam), cert. denied, 100 S. Ct. 1647 (1980).

${ }^{18 s}$ United States v. Bryza, 522 F.2d 414 (7th Cir. 1975); United States v. George, 477 F.2d 508 (7th Cir.), cert. denied, 414 U.S. 827 (1974). Both George and Bryza involved schemes in which a corporate purchasing agent received payments in connection with secret agreements with his employer's suppliers. The facts in each case do not clearly indicate whether there was a direct causal relationship between the defendant's receipt of the payments and his deception of the corporate victim-that is, whether the defendant received payment directly from corporate funds. The George court found this issue of causation irrelevant to its holding, id. at 512. Both courts, however, based their affirmation of the convictions squarely upon the intangible-rights doctrine, which was characterized as the deprivation from an employer of its employee's "loyal and honest services." Id. See Bryza, 522 F.2d at 422. Possibly the best interpretation of George and Bryza is that the Seventh Circuit simply used the intangible-rights doctrine to avoid the difficult problem of establishing, from complex and ambiguous facts, that the defendants had received direct economic benefit from the corporate victims of their deceptive schemes. To the extent that the court based such an approach on Procter \& Gamble, it was without genuine authority for its holdings. 
under some circumstances a breach of fiduciary duty amounts to the deception necessary for fraud. These early cases, to which the origin of the intangible-rights theory seems to have been traced by later courts, actually left the economic requirement of fraud intact.

\section{Conclusion}

By invoking a theory of intangible political rights, several federal courts have attempted to convert the federal mail fraud statute-section 1341-into a weapon for fighting political corruption when the citizenry has not been deprived of anything of economic value. The mere deprivation of the right to honest government, according to the intangible-rights theory, constitutes fraud for purposes of section 1341 .

Analysis of the legislative history of section 1341, however, demonstrates that the section's reach should be limited to fraudulent conduct that results in the acquisition of money or property from the victim. The meaning of fraud in the nineteenth century, when the mail fraud statute was originally adopted, bolsters such a reading. Moreover, the Supreme Court and lower federal court decisions that have been cited for an intangible-rights construction of section 1341 do not provide support. The use of section 1341 against politically corrupt politicians thus remains contrary to Congress's original intent. Until Congress amends the section, such use should not receive the imprimatur of the courts.

W. Robert Gray 